\begin{tabular}{c} 
Volume and Issues Obtainable at Center for Sustainability Research and Consultancy \\
Journal of Business and Social Review in Emerging Economies \\
ISSN: 2519-089X (E): 2519-0326 \\
Volume 3: Issue 1 June 2017 \\
CSRᄃ \\
Journal homepage: www.publishing.globalcsrc.org/jbsee \\
\hline
\end{tabular}

\title{
Examining the Role of Public Relations Departments in Universities and their Relationships with the Graduates in Palestine
}

\author{
${ }^{1}$ Mohammed W. Almudallal, ${ }^{2}$ Norhani Bakri \\ ${ }^{1} \mathrm{PhD}$ Candidate, Faculty of Management, UniversitiTeknologi Malaysia (UTM), Skudai, Johor, Malaysia, \\ mohwaleed1984@gmail.com \\ ${ }^{2}$ Associate Prof, Faculty of Management, UniversitiTeknologi Malaysia (UTM), Skudai, Johor, Malaysia, \\ nhani_b@yahoo.com
}

\begin{tabular}{|c|c|}
\hline \multirow{4}{*}{$\begin{array}{l}\text { ARTICLEDETAILS } \\
\text { History } \\
\text { Revised format: May } 2017 \\
\text { AvailableOnline: June } 2017\end{array}$} & \multirow{11}{*}{$\begin{array}{l}\text { ABSTRACT } \\
\text { Purpose:This paper aims to examine the role of public relations } \\
\text { departments in universities and how they deal with graduates. Universities } \\
\text { in general have PR departments that are created to increase the missions } \\
\text { and strengthen the visions. Frequently, the PR department is responsible } \\
\text { for enhancing the objectives of the university to improve its image to } \\
\text { publics. This study therefore investigates the extent of the PR role as a } \\
\text { tool for facilitating the achievement of the objectives of universities. Data } \\
\text { for the study was collected from a sample of one hundred and twenty } \\
\text { (120) respondents sampled from graduates of the university. Which \% } 78.3 \\
\text { males and \% } 21.7 \text { females from different districts in Gaza Strip in } \\
\text { Palestine. Findings from the study showed that the administration of the } \\
\text { PR departments reinforces the affiliation of graduates to their universities. } \\
\text { Furthermore, the PR departments mainly participate in holding graduation } \\
\text { ceremonies and in coordinating with other departments. The PR } \\
\text { departments continue with the graduates to assist them find suitable } \\
\text { careers in the future. They also communicate with the graduates through } \\
\text { various means of social connectivity websites. }\end{array}$} \\
\hline & \\
\hline & \\
\hline & \\
\hline Keywords & \\
\hline & \\
\hline Employment opportunities, & \\
\hline Continuity in communication, & \\
\hline Palestine. & \\
\hline JEL C & \\
\hline & \\
\hline
\end{tabular}

(C) 2017 The authors, under a Creative Commons Attribution-

NonCommercial 4.0

Corresponding author's email address: mohwaleed1984@gmail.com

Recommended citation:Almudallal, M. W. \& Bakri, N., (2017).Examining the Role of Public Relations

Departments in Universities and their Relationships with the Graduates in Palestine.Journal of Business and Social

Review in Emerging Economies, 3 (1),101-108.DOI: https://doi.org/10.26710/jbsee.v3i1.183

\section{Introduction}

Public Relations (PR) is a management function that focuses on telling the story of the university such as: its mission, vision, goal, history, traditions and requirements in order topublics which are significant to the success of the university. Public relations began playing an important and vital role in communicatingthe aims, objectives and needs of higher education in the late of $19^{\text {th }}$ century (Bonfiglio,1990; Cutlip, Center, $\&$ Broom, 1985).As the public university became a more complexinstitution with a growing potential of factors, the need for and role of publicrelations became increasingly important.Public relations plays a vital role in helpinguniversity administrators to show clearly their aspirations, goals and objectivesin order to operate and compete (Wilson, 2009). Its operations differ from one university to another mainly because of differences in mission, vision, goals, values and services that a university was established for (Aikins\&Adu-Oppong, 2015). 
Today, universities have adopted professional public relations activities owing to rapid expansion of its environments, increase in staff and students population and the changing social issues that they deal with. Owing to this expansion, communication effectiveness has also become a hard task for most universities in dealing with graduates (Aikins\&Adu-Oppong, 2015). This suggests that there is a need to look for effective ways of sharing information with graduates in particular during their stay in the university and after. Therefore, new and more innovative ways of facilitating communication between the university and its graduates must be sought. In Palestine, although the universities have public relations departments and units, they have not been given the same statue as other departments. A critical look at universities, reveal that just as other sections of the university play roles with specific objectives, public relations is required to perform certain responsibilities that ensure the achievement of the goals of the university involved. So this current study seeks to achieve the following objectives: First, to clarify the appropriate way that the departments of public relations in the Palestinian universities ensure the success of their programs and reaching their message to the masses of students properly. Second, to have illustrative results that contain evaluations of the clear role played by public relations departments in universities towards the masses of students. Third, to show the duties and functions of public relations in the Palestinian universities towards the masses of students. This will be followed by the methodology for the study, findings and analysis of the study. The final section deals with managerial implications for the universities and conclusion.

\section{Literature Review}

\subsection{Overview of Public Relations (PR)}

Public Relations (PR) practice is planned and continued effort to establish and keep mutual understanding between an organisation and its publics (Grunig, 2001). PR consists of all forms of planned communication between an organisation and its publics for the purpose of achieving objectives in regard with reciprocal understanding (Jefkins, 2006). The literature presents PR as a management tool, which uses the characteristics of management (e.g. planning, decision making, and research) to reinforce the organization's ability to establish valuable relationships on which the corporate vision and mission depend on (Grunig, 2001). The second trend in the literature presents PR as a communication management, which focuses on the flow of communication between an organization and its publics to achieve effective mutual relationships (Grunig, 2001). The third trend of literature presents PR as relationship management which can provide important and valuable support in relationship management through communications (Valentini, 2016). Consequently, communication is a property of those relationships rather than a channel between organizations and publics (Molleda\& Ferguson, 2004).

\subsection{Educational Public Relations Functions}

PR plays a very critical role in almost every educational institution. Educational public relations officers help students especially graduates and work with various groups within those institutions. They distribute newsletters containing information about campus events, build and keep in contact with alumni, lecturers, staff and students. According to National School Public Relations Association (2012), educational public relations is a planned and systematic management function in order to improve the programs and services of an educational organization. This indicates that activities of educational public relations is a two-way communication between the institution and its audiences specially graduates. A communications plan affords the means by which resources and information can be retrieved and managed easily for the benefit of an institution. Further, (Wilcox, et al., 2001) shed light on the functions of PR and believe that its practice is a process which operates and develops different techniques of communication. Accordingly, (Pirozek\&Heskova, 2003) examined PR practice and found that two-way regular strategies of research and feedback systems assist the university to gain a better understanding of the attitudes of its main publics. Kaverina (2003) also showed that two-way regular efforts strengthen the relationship between the university and its publics. Additionally, (White \& Park, 2010) acknowledge that PR is important in providing positive information to the society.

National School Public Relations Association (2012) confirms that one of the educational public relations functions is to provide counseling to graduates, take a proactive attitude, predict problems and give 
solutions. Newson \& Carrell (2001) added that public relations staffs must be aware of the feelings of graduates, parents, supporters and partners. This asserts that educational public relations officers must guide students on educational planning, effective decisions making concerning programs of study, resolving conflicts, recognizing and utilizing academic strengths among others. This makes the function very comprehensive. Basically, the task of the public relations department is to make sure internal publics such as: graduates and potential graduates are aware of several aspects of PR efforts to be fulfilled. One of the other hand, one of the most important of PR functions is to work about damage control (Clow\&Baack, 2007). Damage control is reacting to negative events caused by a university error. In the words of (Clow\&Baack, state that a strong university image, which took years to build, may be destroyed in a few weeks. Therefore, defending a university's image and handling damage control takes the form of proactive prevention strategies of which the main purpose is to reduce image damage that could harm the university.

\subsection{Research Framework}

For research framework, the researcher will survey the three factors: the graduation ceremonies factor, the employment opportunities factor and the continuity in communication factor and how they influence the PR Department of the university. The role of public relations departments at the university in establishing relationships with graduates in Palestine.

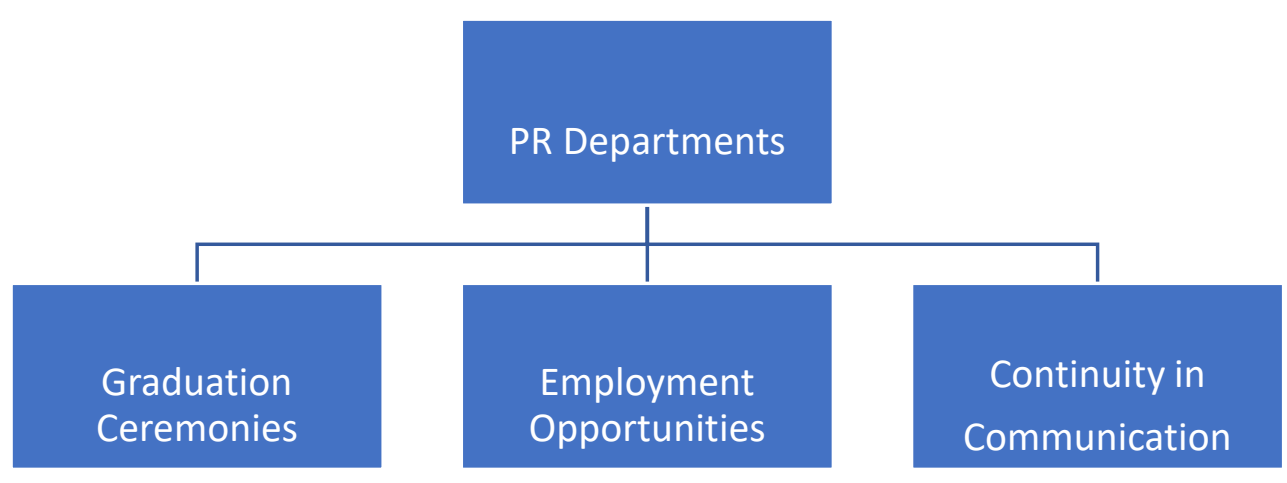

Figure 1: Conceptual model of PR departments in the Palestinian universities.

\section{Research Methodology}

This section describes the research methodology used in this study. It explains the research design, target population, data collection and data analysis used in the study. The current study aims at investigating the role of public relations departments in universities and their relationships with the graduates. The quantitative method is used in this study by answering the survey questions and analysing the collected data using SPSS. The target population for this study incudes Islamic University of Gaza - IUG alumni, obtained from the alumni database system. The population size is 120 from different districts of Gaza Strip.

\section{Results and Discussion}

This section presents and analyzes the data gathered from the questionnaires. All data will be analyzed by computer, the SPSS software was used to enter the data and design the graphs in order to help the researcher to explore and analyze the data.

\subsection{Detailed Analysis of Results}

Questionnaires were sent to the respondents (graduates) in the Islamic University of Gaza - IUG, by attaching to emails to be handed to them. 


\subsection{Profile of the respondents}

\subsubsection{Gender}

The table below shows that among the respondents, $78.3 \%$ males and $21.7 \%$ females.

Table.1

\begin{tabular}{|c|c|c|c|c|c|c|}
\hline \multicolumn{7}{|c|}{ Statistics } \\
\hline gender & & & education & & & CGPA \\
\hline $\mathbf{N}$ & Valid & 120 & 120 & 120 & 120 & 120 \\
\hline Missing & $\overline{0}$ & & & & 0 & 0 \\
\hline
\end{tabular}

Table.2: Gender

\begin{tabular}{|c|c|c|c|c|c|}
\hline Frequen & \multicolumn{2}{|c|}{ Percent } & \multicolumn{2}{|c|}{ Valid Percent } & $\begin{array}{c}\text { Cumulative } \\
\text { Percent }\end{array}$ \\
\hline Valid & Male & 94 & 78.3 & 78.3 & \begin{tabular}{l|l|} 
& 78.3 \\
\end{tabular} \\
\hline Female & \multirow{2}{*}{\multicolumn{2}{|c|}{120}} & & 21.7 & 100.0 \\
\hline Total & & & \multicolumn{2}{|c|}{100.0} & 100.0 \\
\hline
\end{tabular}

\subsubsection{Age}

The greatest percentage of the respondents is (34.2\%) are between 27 to 31 years of age. Followed by those between the ages of 32 to $36(30 \%)$, followed by those between the ages of 22 to $26(21.7 \%)$. Between the ages of 37 and above is $(14.2 \%)$.

Table.3: $\quad$ Age

\begin{tabular}{|l|l|l|l|l|l|l|}
\hline \multicolumn{2}{|c|}{ Age } \\
\hline Frequency & \multicolumn{2}{|l|}{ Vercent } & \multicolumn{2}{l|}{$\begin{array}{l}\text { Valid Percent } \\
\text { Percent }\end{array}$} \\
\hline Valid & $22-26$ & 26 & 21.7 & 21.7 \\
\hline $27-31$ & 41 & 34.2 & 34.2 & 55.8 \\
\hline 32 to 36 & 36 & 30.0 & 30.0 & 85.8 \\
\hline 37 and above & 17 & 14.2 & 14.2 & 100.0 \\
\hline Total & 120 & 100.0 & 100.0 \\
\hline
\end{tabular}

\subsubsection{Education}

The table bellows shows that among the respondents, $60 \%$ was bachelor and $40 \%$ were masters. This indicates that majority of the respondents were has bachelor.

Table.4: Education

\begin{tabular}{|l|l|l|l|l|l|}
\hline Frequency & \multicolumn{2}{l|}{ Percent } & \multicolumn{2}{l|}{ Valid Percent } & $\begin{array}{l}\text { Cumulative } \\
\text { Percent }\end{array}$ \\
\hline Valid & $\begin{array}{l}\text { bachelor } \\
\text { degree }\end{array}$ & 72 & 60.0 & 60.0 & 60.0 \\
\hline Master & 48 & & & & \\
\hline Total & 40.0 & & 40.0 & 100.0 \\
\hline
\end{tabular}

Table.5: Origin

\begin{tabular}{|c|c|c|c|c|c|c|}
\hline \multicolumn{7}{|c|}{ Origin } \\
\hline Frequency & \multicolumn{3}{|c|}{ Percent } & \multicolumn{2}{|c|}{ Valid Percent } & Cumulative Percent \\
\hline Valid & Rafah & 25 & & 20.8 & 20.8 & \begin{tabular}{l|l|} 
& 20.8 \\
\end{tabular} \\
\hline Khanyonis & \multicolumn{2}{|l|}{21} & \multicolumn{2}{|l|}{$\mathbf{1 7 . 5}$} & $\mathbf{1 7 . 5}$ & 38.3 \\
\hline Alwosta & \multicolumn{2}{|l|}{7} & \multicolumn{2}{|l|}{5.8} & 5.8 & 44.2 \\
\hline Gaza & \multicolumn{2}{|l|}{40} & \multicolumn{2}{|l|}{33.3} & 33.3 & 77.5 \\
\hline Alshamal & \multicolumn{2}{|l|}{27} & 22.5 & & \multirow[t]{2}{*}{22.5} & \begin{tabular}{l|l|}
100.0 \\
\end{tabular} \\
\hline Total & \multicolumn{3}{|l|}{120} & 100.0 & & 100.0 \\
\hline
\end{tabular}

Table.6 


\begin{tabular}{|l|l|l|l|l|l|l|l|}
\hline \multicolumn{7}{|c|}{ CGPA } \\
\hline Frequency & Percent & \multicolumn{2}{l|}{ Valid Percent } & Cumulative Percent \\
\hline Valid & $\begin{array}{l}\text { From 60\% to } \\
69 \%\end{array}$ & 33 & 27.5 & 27.5 & 27.5 \\
\hline $\begin{array}{l}\text { from 70\% to } \\
79 \%\end{array}$ & 26 & 21.7 & & 21.7 & 49.2 \\
\hline $\begin{array}{l}\text { from 80\% to } \\
89 \%\end{array}$ & 18 & 15.0 & 15.0 & 64.2 \\
\hline $\begin{array}{l}\text { from 90\% to } \\
\text { 99\% }\end{array}$ & 43 & 35.8 & 35.8 & 100.0 \\
\hline Total & & & 100.0 & & 100.0 \\
\hline
\end{tabular}

\section{Table 5.6 CGPA}

Table.7: Reliability

Scale: ALL VARIABLES

Case Processing Summary

\begin{tabular}{|l|l|l|l|}
\hline \multicolumn{2}{|l|}{} & \multicolumn{2}{l|}{$\%$} \\
$\mathbf{N}$ & \multicolumn{2}{l|}{} \\
\hline Cases & Valid & $\mathbf{1 2 0}$ & $\mathbf{1 0 0 . 0}$ \\
\hline Excludeda & $\mathbf{0}$ & $\mathbf{. 0}$ \\
\hline Total & $\mathbf{1 2 0}$ & $\mathbf{1 0 0 . 0}$ \\
\hline
\end{tabular}

a. Listwise deletion based on all variables in the procedure.

\section{Table.8}

\begin{tabular}{|l|l|}
\hline \multicolumn{2}{|l|}{ Reliability Statistics } \\
\hline Cronbach's Alpha & N of Items \\
\hline .794 & 5 \\
\hline
\end{tabular}

RELIABILITY /VARIABLES=gradcerem1 gradcerem2 gradcerem3 gradcerem4 gradcerem5 /SCALE('ALL VARIABLES') ALL /MODEL=ALPHA.

Table.9: Scale: ALL VARIABLES

\begin{tabular}{|l|l|l|l|l|}
\hline Case Processing Summary N & \multicolumn{4}{l|}{$\%$} \\
\hline Cases & Valid & 120 & 100.0 \\
\hline Excluded(a) & 0 & .0 & \\
& & & & \\
\hline Total & 120 & 100.0 \\
\hline
\end{tabular}

Table.10

\begin{tabular}{|l|l|}
\hline \multicolumn{2}{|l|}{ Reliability Statistics } \\
\hline Cronbach's Alpha & N of Items \\
\hline .855 & 5 \\
\hline
\end{tabular}

RELIABILITY /VARIABLES=employment 1 employment 2 employment 3 employment 4 employment5 /SCALE('ALL VARIABLES') ALL /MODEL=ALPHA. 
Table.11

Scale: ALL VARIABLES Case Processing Summary

\begin{tabular}{|l|l|l|l|}
\hline $\mathbf{N}$ & \multicolumn{2}{|l|}{$\%$} \\
\hline Cases & Valid & $\mathbf{1 2 0}$ & \multicolumn{1}{l|}{100.0} \\
\hline Excludeda & $\mathbf{0}$ & $\mathbf{0}$ \\
\hline Total & $\mathbf{1 2 0}$ & $\mathbf{1 0 0 . 0}$ \\
\hline
\end{tabular}

a. Listwise deletion based on all variables in the procedure.

Table.12

Reliability Statistics

\begin{tabular}{|l|l|}
\hline Cronbach's Alpha & $\mathrm{N}$ of Items \\
\hline .815 & 5 \\
\hline
\end{tabular}

RELIABILITY /VARIABLES=communication1 communication2 communication3 communication4 communication5 /SCALE('ALL VARIABLES') ALL /MODEL=ALPHA.

Table.13

Scale: ALL VARIABLES Case Processing Summary

\begin{tabular}{|l|l|l|l|}
\hline $\mathbf{N}$ & \multicolumn{3}{|l|}{ \% } \\
\hline Cases & Valid & $\mathbf{1 2 0}$ & $\mathbf{1 0 0 . 0}$ \\
\hline Excludeda & $\mathbf{0}$ & $\mathbf{. 0}$ \\
\hline Total & $\mathbf{1 2 0}$ & $\mathbf{1 0 0 . 0}$ \\
\hline a & & \\
\hline
\end{tabular}

a. Listwise deletion based on all variables in the procedure.

Table.14

\begin{tabular}{|l|l|}
\hline Reliability Statistics \\
\hline Cronbach's Alpha & N of Items \\
\hline .866 & 5 \\
\hline
\end{tabular}

RELIABILITY /VARIABLES=PRgraduates1 PRgraduates2 PRgraduates3 PRgraduates4 PRgradautes5 /SCALE('ALL VARIABLES') ALL /MODEL=ALPHA.

Table.15

\begin{tabular}{|c|c|c|c|}
\hline $\begin{array}{c}\text { Reliability Test Result } \\
\text { Variable }\end{array}$ & No of items & Cronbach's Alpha & Remark \\
\hline Graduation Ceremonies & 5 & 0.794 & High reliability \\
\hline $\begin{array}{c}\text { Employment } \\
\text { Opportunities }\end{array}$ & 5 & 0.855 & High reliability \\
\hline $\begin{array}{c}\text { Continuity in } \\
\text { Communication }\end{array}$ & 5 & 0.815 & High reliability \\
\hline PR Departments & 5 & 0.866 & High reliability \\
\hline
\end{tabular}

\section{Recommendations and Conclusion}

The study recommends the following:

In light of the study results, the researcher provides a number of recommendations that the he hopes will 
benefit the Palestinian universities, graduates, researchers and who are interested in this field.

- Organizing training programs for public relations staff.

- Organizing visits for graduates and strengthening the relationships between PR staff and graduates in order to achieve its objectives and goals.

- The top management of universities need to support the PR administration in undertaking its programs professionally.

- Conducting a research to diagnose points of weaknesses concerning the relationship between PR departments and graduates.

- Proposing practical solutions which guarantee good relationships with the student community.

- Working on the graduates participation in the university activities, and motivate them to volunteer work, and all that would make them love the university and feel so proud of it.

- The necessity to measure the public opinion of its importance, and working on conveying the opinions and suggestions of students and their proposals for the top management.

- The need for a database of graduates in the public relations departments to communicate with them and invite them to participate in the university activities.

The overall aim of this study is to clarify the role played by public relations departments at the Palestinian universities and their influence ongraduates, in addition to assess their performancein order to have results that mostly benefit the graduates and the employees in any educational institutions. Further, this study is also to explain the role that played by public relations departmentstowards the masses of students, and to figure out the appropriate method that ensuressuccess and competition.

\section{References}

Aikins. E. D and Adu-Oppong. A. A (2015). Using Public Relations as a Management Tool in Tertiary Institutions. Afro Asian Journal of Social Sciences, Vol, VI, No 2, pp. 1-15. ISSN: 2229 - 5313.

Bonfiglio, R. A. (1990). The history of public relations in American higher education in the twentieth century: From self-interest to national interest. Unpublished Dissertation, Columbia University, New York.

Clow, E. K. \& Baack, D. (2007). Integrated Advertising, Promotion, and Marketing Communication, 3rd Edition, New Jersey: Pearson Education Inc.

Cutlip, S. M., Center, A. H., \& Broom, G. M. (1985). Effective public relations. education in the Czech Republic. Higher Education in Europe, 4, 487-494.

Englewood Cliffs, NJ: Prentice-Hall.

Grunig, J. E. (2001). The role of public relations in management and its contribution to organizational and societal effectiveness. Institute for Public Relations, http://www. instituteforpr. org/research_single/public_relations_in_management.

Jefkins F., (2006); "Public Relations"; London, Pitman Publishing

Molleda, J. C., \& Ferguson, M. A. (2004). Public relations roles in Brazil: Hierarchy eclipses gender differences. Journal of Public Relations Research,16(4), 327-351.

Newson, D. \& Carrell, B. (2001). Public Relations Writing: Form and Style, 6 th Edition, U.S.A. Wadsworth: Thompson learning Inc.

Pirozek, P. \& Heskova, M. (2003). Approaches to and instruments of public relations: Higher Publishers.

Valentini, C. (2016). Public relations as relationship management. A relational approach to the study and practice of public relations.

White, C. \& Park, J. (2010). Public Perceptions of Public Relations. Public Relations Review 36 319-324.

Wilcox et al (2005); "Public Relations Strategies and Tactics"; 2nd Edition; Harper Collins

Wilson, T. A. (2009). The role of communication messages and public relations strategies in the higher education" public good" debate: a study of four public research universities. 
